\title{
Effect of gum arabic (Acacia senegal) addition on physicochemical properties and sensory acceptability of roselle juice
}

\author{
${ }^{1}$ Tuan Azlan, T.N.N., ${ }^{1, * H a m z a h, ~ Y . ~ a n d ~}{ }^{2}$ Mohd Abd Majid, H.A. \\ ${ }^{1}$ Faculty of Fisheries and Food Science, Universiti Malaysia Terengganu, 21030 Kuala Nerus, Terengganu, \\ Malaysia \\ ${ }^{2}$ Faculty of Hotel and Tourism Management, Universiti Teknologi MARA (UiTM), Malaysia, Terengganu \\ Branch, Dungun Campus
}

\section{Article history: \\ Received: 18 August 2019 \\ Received in revised form: 1 \\ October 2019 \\ Accepted: 2 October 2019 \\ Available Online: 20 October 2019}

Keywords:

Gum Arabic,

Physicochemical properties,

Sensory acceptability,

Roselle juice

DOI:

https://doi.org/10.26656/fr.2017.4(2).293

\begin{abstract}
Roselle has a brilliant red colour, high in vitamins and has a unique flavour that makes it suitable for juice production. Meanwhile, Gum Arabic (GA) is the edible dried exudate attained from stem and branch of Acacia senegal that contains high dietary fibre which can serve as prebiotic. Therefore, the application of GA into roselle juice might promote health benefits to consumers. GA is categorised as hydrocolloid and its application might affect important properties and acceptability towards the product. Hence, this study was conducted to investigate the effect of different concentrations of Gum Arabic (GA, Acacia senegal) addition $(0 \%, 2 \%, 4 \%$ and $6 \%)$ on physicochemical properties and sensory acceptability of roselle juice. Increasing the GA concentration resulted in increased $\mathrm{pH}$, total soluble solids, viscosity and turbidity values of roselle juice $(p<0.05)$. However, the addition of GA had reduced the total anthocyanin content in roselle juice. For colour analysis, the addition of GA significantly $(\mathrm{p}<0.05)$ reduced the redness $\left(\mathrm{a}^{*}\right)$ and yellowness $\left(b^{*}\right)$ properties. There was no significant difference in all attributes for sensory evaluation except for colour attribute. In conclusion, the addition of GA up to $6 \%$ into roselle juice caused an increase in $\mathrm{pH}$, total soluble solids, viscosity and turbidity, but no effect to the sensory attributes.
\end{abstract}

\section{Introduction}

The awareness of a healthy lifestyle and dietary intake has attracted the attention of consumers towards functional food products. The functional food market had increased due to the foods itself that provide a convenient way to maintain optimum health by offering health benefits which can help to prevent particular diseases (Lau et al., 2013). Functional food products usually were added with functional ingredients, for instance, vitamin E, fibre, calcium, probiotics and prebiotics (Lau et al., 2013). Nowadays, the product that was targeting on gut health like probiotics and prebiotics has gained more attention.

Prebiotic is the substance that indigestible in the small intestine, moves to the colon and used by gut bacteria, thus providing a health benefit that can maintain health (Gibson et al., 2017). The intake of prebiotic can be a dietary strategy to alter the concentration of gastrointestinal microbiota such as Bifidobacteria that can promote health benefits, which consequently may prevent disease. It was reported that prebiotic is capable of preventing cancer and constipation, remove cholesterol, reduce cardiovascular disease risk and act as an immunopotentiator (Patel and Goyal, 2012; Al-Sheraji et al., 2013).

One of the potential prebiotic is Gum Arabic (GA) which is acquired from stems and branches of Acacia senegal (L.) Willdenow or Acacia seyal (fam. Leguminosae) tree (Idris, 2017; Mariod, 2018). It is rich in dietary fibre, indigestible in the stomach and small intestine and thus was fermented in large intestine by the surrounding bacteria (Phillips and Phillips, 2011). Therefore, it shows that GA poses prebiotic characteristic that capable of increasing the Bifidobacteria when it was fermented in large intestine. Besides, it has been reported that intake of GA at an optimal dose of $10 \mathrm{~g}$ daily is capable of providing prebiotic effects to consumers ( Cherbut et al., 2003; Calame et al., 2008).

Considering the health benefits of prebiotic and increased demand for functional foods by consumers, fruit juice has been recommended and is suitable for the 
functional food production due to its bioactive components, and meets the demands on healthy, tasty and practical products (Gomes et al., 2017). Few studies have been carried out to develop fruit juice with prebiotic properties. Previously, a study by da Silva et al. (2014) has suggested the development of cashew juice with oligosaccharides as a potential new functional beverage. Other than that, in a previous study, the addition of FOS (oligofructose and inulin) in apple and orange juice resulted in no significant difference with the control sample during the sensory evaluation, suggesting that the beverages with prebiotics were acceptable by the panellist (Ghavidel et al., 2014). However, the majority of previous studies used oligofructose and inulin as prebiotic. There are limited studies used GA as a prebiotic source.

In a previous study, Niamah et al. (2016) studied the usage of Gum Arabic as prebiotics in yoghurt production. The study reported that the viability of probiotic bacteria was increased after production when $1 \%$ of GA was added to the yoghurt. Moreover, the study also revealed that the addition of $1 \%$ GA improved the nutritional value by increasing the percentage of total solids, carbohydrate and protein. Besides, Nami et al. (2016) also reported that the utilisation of GA gels exhibited better potential for encapsulation of probiotic bacteria in yoghurt due to its prebiotic potentials. However, these studies only carried out on yoghurt and limited studies have been conducted on fruit juice, especially in roselle juice.

Nowadays, roselle has been enticing the attention of food and beverage manufacturers because of its health benefits to the consumers. Roselle has been proven to rich in nutrients like vitamins and polyphenol that might promote antioxidant properties (Jabeur et al., 2017; Riaz and Chopra, 2018). The roselle calyxes extract was found to promote health benefit as an anticancer and capable of reducing the chronic disease for instance hypertension, diabetes mellitus and cardiovascular disease (McKay et al., 2010; Akim et al., 2011; Mardiah et al., 2014; Formagio et al., 2015). Thus, it demonstrated that roselle juice could be an excellent carrier in developing functional beverages with GA as a prebiotic source. However, as GA is categorised as a hydrocolloid, its addition may affect the physicochemical characteristics and organoleptic properties of the juice.

Therefore, the objective of this study was to evaluate the physicochemical properties and sensory acceptability of roselle juice with addition of GA at different concentration level.

\section{Materials and methods}

\subsection{Materials and preparation of roselle juice}

Fresh roselle calyx from UMKL variety was obtained from a local producer. The calyxes were washed with clean water, decored (seeds removal) and air-dried before storage at frozen temperature $\left(-20^{\circ} \mathrm{C}\right)$ until further used. Frozen calyxes were ground for $1 \mathrm{~min}$ using a food blender (Panasonic MX-337, Malaysia) with roselle calyx to water ratio of $1: 20$. Then the sample was extracted by heating at $60^{\circ} \mathrm{C}$ for $15 \mathrm{~min}$. The roselle extract was filtered using a muslin cloth and allowed to cool at room temperature $\left(24^{\circ} \mathrm{C}\right)$. Roselle juice was prepared by adding the roselle extract with $4 \%$ xylitol and $0.03 \%$ stevia as sweetener. Then, the GA powder (A. senegal) was added at a concentration of $0 \%$ (control), 2\%, 4\% and $6 \%$ before the pasteurisation process. The juice was pasteurised at $90^{\circ} \mathrm{C}$ for $30 \mathrm{~s}$ and hot-filled into an amber glass bottle before cooled rapidly to room temperature by immersing in an icy water bath.

\subsection{Physicochemical analysis}

\subsubsection{Titratable acidity and $\mathrm{pH}$ value}

The titratable acidity of each sample was determined by the titration method. About $20 \mathrm{~mL}$ of each sample was titrated with $0.1 \mathrm{~N} \mathrm{NaOH}$ until reaching the endpoint of $\mathrm{pH} 8.2 \pm 0.2$ using a $\mathrm{pH}$ meter (Thermo Scientific Orion Star A111, USA). The total acidity of sample was expressed as a percentage of malic acid in prebiotic roselle juice (Mgaya-Kilima et al., 2014). For pH value determination, it was obtained by using a calibrated $\mathrm{pH}$ meter (Thermo Scientific Orion Star A111, USA) at $25^{\circ} \mathrm{C}$

\subsubsection{Total soluble solid}

The total soluble solid content of prebiotic roselle juice was measured by using a refractometer (Milwaukee MA871, USA) at $20^{\circ} \mathrm{C}$. The result was expressed as degree Brix ( ${ }^{\circ}$ Brix).

\subsubsection{Viscosity}

The viscosity of sample was determined using a rotatable viscometer (Brookfield DV-II+ Pro, USA) with no. 2 spindle at $100 \mathrm{rpm}$ (Saxena et al., 2014). The position and setting of the viscometer were adjusted to obtain a precise measurement. Prior to the experiment, the spindle was immersed for $30 \mathrm{~s}$ in the sample for equilibrium. The reading was taken when it became stable, basically after $10 \mathrm{~s}$ of rotation or at $10^{\text {th }}, 11^{\text {th }}$ and $12^{\text {th }}$ cycle (Oke et al., 2010). The measurement of viscosity was expressed in millipascal-second (mPas). 


\subsubsection{Turbidity}

The turbidity of roselle juice was determined according to Sreenath and Santhanam (1992) by measuring the absorbance of samples at $650 \mathrm{~nm}$ using a UV-Vis spectrophotometer (Merck Spectroquant Pharo 300 Spectrophotometer, Germany). Distilled water was used as blank and the result was expressed as absorbance at $650 \mathrm{~nm}\left(\mathrm{Abs}_{650 \mathrm{~nm}}\right)$.

\subsubsection{Total anthocyanin content}

The anthocyanin content in roselle juice was determined by $\mathrm{pH}$ differential method according to method by Lee (2005). Prior to the analysis, two $\mathrm{pH}$ buffers, which was potassium chloride buffer $(\mathrm{pH} 1.0)$ and sodium acetate buffer ( $\mathrm{pH} 4.5)$ was prepared. For the analysis, approximately $3 \mathrm{~mL}$ of sample was placed in two different test tubes and diluted to $15 \mathrm{~mL}$ with the corresponding buffer. Then, the solutions were vortexed at $2000 \mathrm{rpm}$ for $1 \mathrm{~min}$ and equilibrated in the dark for 20 mins. The absorbance was measured at wavelength of $520 \mathrm{~nm}$ and $700 \mathrm{~nm}$ by UV-Vis spectrophotometer (Merck Spectroquant Pharo 300 Spectrophotometer, Germany). Distilled water was used as blank. Then, the total anthocyanin content in the sample was calculated according to the following formula and was expressed as $\mathrm{mg}$ cyanidin-3-glucoside equivalent/100 mL sample $(\mathrm{mg} / 100 \mathrm{~mL})$ :

Total anthocyanin content $=\frac{\mathrm{A} \times \mathrm{Mw} \times \mathrm{DF} \times 1000}{\in L}$

Where $\mathrm{Mw}=$ molecular weight $(\mathrm{MW})$ of cyanidin- 3glucoside $(449.2 \mathrm{~g})$; $\mathrm{DF}=$ the dilution factor; $\mathrm{Mw}=$ is the molar extinction coefficient for cyanidin-3-glucoside $(26,900 \mathrm{~L} / \mathrm{mol} / \mathrm{cm}) ; \quad \mathrm{L}=$ the path length of the spectrophotometer cell $(1.0 \mathrm{~cm})$; and $\mathrm{A}=$ the difference of sample absorbance between $\mathrm{pH} 1.0$ and 4.5 calculated with the following equation:

$$
\mathrm{A}=(\mathrm{A} 520-\mathrm{A} 700)_{\mathrm{ph} 1.0}-(\mathrm{A} 520-\mathrm{A} 700)_{\mathrm{pH} 4.5}
$$

\subsubsection{Colour}

Colour measurement was carried out using a chromameter (Konica Minolta Chroma Meter CR-400, Japan) calibrated with a standard white tile. An amount of $25 \mathrm{~mL}$ of the sample was placed in a glass petri dish, covered with a protective cap and the colour measurement was taken. The colour parameters were recorded at room temperature, according to CIE $\mathrm{L}^{*}$, a* and $b^{*}$ colour values. The $L^{*}$ value indicates lightness, $\mathrm{a}^{*}$ value represents greenness to redness while yellowness $\left(b^{*}\right)$ value measures blueness to yellowness of the sample.

\subsection{Sensory acceptability}

Sensory acceptability test was conducted for roselle juice with different concentrations $(0 \%, 2 \%, 4 \%$, and $6 \%$ ) of GA addition. A total of fifty untrained panellists consist of Universiti Malaysia Terengganu (UMT) students and staffs were involved in the evaluation. Each of panellist was served with approximately $30 \mathrm{~mL}$ of juice (for each formulation) and was asked to evaluate according to five sensory attributes for instance colour, odour, viscosity, taste and overall acceptability. The acceptability of prebiotic roselle juice was evaluated using a 5-point hedonic scale anchored by: $1=$ 'Dislike extremely'; 2 = 'Dislike moderately'; 3 = 'Neither like nor dislike'; $4=$ 'Like moderately'; $5=$ 'Like extremely' (Granato et al., 2010).

\subsection{Experimental design and statistical analysis}

The experiment was conducted using a complete randomised design (CRD) with a one-way treatment structure. Each sample was prepared in three independent replication and the results were expressed as mean values and standard deviation (SD). One-way analysis of variance (ANOVA) was performed at $95 \%$ confidence level. Then, the significant differences between means were then analysed by Fisher's Least Significance Difference Test. Data were analysed using Minitab 19.0.

\section{Results and discussion}

\subsection{Physicochemical properties of roselle juice}

\subsubsection{Titratable acidity and $\mathrm{pH}$ value}

Roselle juice with $0 \%$ (control), $2 \%, 4 \%$ and $6 \%$ of GA were analysed for titratable acidity by titration method. Titratable acidity determines the concentration of total acid in a sample such as malic acid, citric acid, tartaric acid and lactic acid and it is usually expressed as a percentage of the predominant organic acid (Tyl and Sadler, 2017). According to Al-Wandawi (2015), Jabeur et al. (2017) and Jung et al. (2013), roselle calyx had been found to have a high percentage of malic acid as compared to other types of acid. Therefore, the titratable acidity in the current study was expressed in percentage of malic acid (\% Malic Acid). The result for titratable acidity of roselle juice with GA addition is summarised in Table 1.

As can be seen in Table 1, the titratable acidity values of all samples were between $0.12 \pm 0.01$ and $0.13 \pm 0.01 \%$ of malic acid. These values were found to be lower than values reported by Mgaya-Kilima et al. (2014) and Cisse et al. (2012) in roselle extract with the values of $1.92 \pm 0.00$ and $19.00 \pm 7.00 \%$ of malic acid, respectively. The difference in the titratable acidity value 
Table 1. Physicochemical properties of roselle juice with different percentages of Gum Arabic (GA)

\begin{tabular}{lcccc}
\hline Properties & A & B & C & D \\
\hline Titratable acidity (\% Malic Acid) & $0.12 \pm 0.01^{\mathrm{a}}$ & $0.12 \pm 0.01^{\mathrm{a}}$ & $0.13 \pm 0.01^{\mathrm{a}}$ & $0.13 \pm 0.01^{\mathrm{a}}$ \\
$\mathrm{pH}$ & $2.59 \pm 0.04^{\mathrm{d}}$ & $3.20 \pm 0.02^{\mathrm{c}}$ & $3.45 \pm 0.02^{\mathrm{b}}$ & $3.61 \pm 0.02^{\mathrm{a}}$ \\
Total Soluble Solid ( ${ }^{\mathrm{o}}$ Brix) & $5.2 \pm 0.3^{\mathrm{d}}$ & $6.8 \pm 0.3^{\mathrm{c}}$ & $8.5 \pm 0.2^{\mathrm{b}}$ & $10.5 \pm 0.3^{\mathrm{a}}$ \\
Viscosity (mPas) & $11.6 \pm 0.00^{\mathrm{d}}$ & $14.93 \pm 0.23^{\mathrm{c}}$ & $20 \pm 0.40^{\mathrm{b}}$ & $25.07 \pm 0.611^{\mathrm{a}}$ \\
Turbidity (Abs ${ }_{650 \mathrm{~nm})}$ & $0.2 \pm 0.007^{\mathrm{c}}$ & $0.257 \pm 0.03^{\mathrm{b}}$ & $0.276 \pm 0.01^{\mathrm{b}}$ & $0.413 \pm 0.02^{\mathrm{a}}$ \\
Total anthocyanin content (mg/100 mL) & $83.74 \pm 2.17^{\mathrm{a}}$ & $72.8 \pm 1.04^{\mathrm{b}}$ & $67.19 \pm 1.13^{\mathrm{c}}$ & $63.04 \pm 2.19^{\mathrm{c}}$ \\
\hline
\end{tabular}

Each value is expressed as mean \pm standard deviation $(\mathrm{n}=3)$. Different superscripts in the same row indicate significant differences (p<0.05); A: 0\% GA; B: 2\% GA; C: 4\% GA; D: 6\% GA.

is possibly due to the difference in roselle varieties and the methods of preparation in terms of their roselle to water ratio, extraction procedure and the preservatives added to the juice. The previous study extracted the roselle juice at ratio of $1: 10$ and 1:15 (roselle calyx: water) and added preservatives such as potassium sorbate, sodium benzoate, and citric acid into the juice which might possibly contribute to the increase of titratable acidity values (Cisse et al., 2012; MgayaKilima et al., 2014).

Besides, the addition of GA did not have a significant effect on titratable acidity of roselle juice. A similar result was reported by Nwaokoro and Akanbi (2015) who found that the addition of hydrocolloids such as xanthan gum and carboxyl methylcellulose (CMC) into tomato carrot juice does not significantly affect the titratable acidity value. Other than that, a previous research works on cow milk whey beverages also showed no changes in titratable acidity when $2 \%$ of hydrocolloid CMC or high methoxyl pectin (HMP) was added (Talpur et al., 2016). Therefore, this can be assumed that the addition of GA did not cause any substantial changes in titratable acidity, may due to the fact that addition of GA does not contribute to the total acid in the juice.

Other than that, Table 1 also shows the $\mathrm{pH}$ of roselle juice with different concentrations of GA addition. Although the titratable acidity values were determined similar for all samples, however, the $\mathrm{pH}$ values were significantly different between each other. The result demonstrated that increasing the concentration of GA from $2 \%$ to $6 \%$ produced less acidic property of the juice. The increase in $\mathrm{pH}$ is expected due to the $\mathrm{pH}$ of GA itself ( $\mathrm{pH} 4.5$ ) was higher than $\mathrm{pH}$ of roselle extract $(\mathrm{pH}$ 2.6) where its addition into roselle juice may contribute to increasing the $\mathrm{pH}$ of the final product (Idris, 2017). Similarly, a previous study by Shukri et al. (2014) also found that addition of hydrocolloids such as guar gum and xanthan gum significantly increased the $\mathrm{pH}$ of tapai pulut (fermented glutinous rice) ice cream due to the properties of the hydrocolloid that act as a stabiliser and thus stabilised the $\mathrm{pH}$ when in acidic condition.

\subsubsection{Total soluble solid}

Total soluble solid (TSS) is referred to the sum of solids that dissolved in a solution, primarily the sugar like sucrose, fructose and glucose, fruit acids and other soluble solids like pectins and minerals (Magwaza and Opara, 2015). As shown in Table 1, the TSS was significantly $(\mathrm{p}<0.05)$ increased with the increase of GA concentration in roselle juice. The result of the present study is in accordance with the finding of previous researchers who reported that the addition of hydrocolloid (carboxymethyl cellulose or Arabic gum) had increased the TSS value in soursop velva (Parnanto et al., 2018). The TSS may increase due to the structure of the hydrocolloid, which consists of linear and watersoluble polysaccharides as well as simple sugars that can increase the TSS value (Parnanto et al., 2018). In the current study, increased TSS of the juice with different concentrations of GA was mainly due to the composition of GA that consists of L-arabinose, D-galactose, Dglucuronic acid and L-rhamnose (Dauqan and Abdullah, 2013; BeMiller, 2019).

\subsubsection{Viscosity}

Viscosity is an important parameter that can affect the quality and consumer acceptance of juice (Nayak et al., 2017). Table 1 shows that the viscosity of roselle juices increased $(p<0.05)$ in line with the increase of GA. A similar trend was observed by Aghajanzadeh et al. (2017), who found that as the concentration of xanthan gum increased from 0.1 to $0.2 \%$, the viscosity of watermelon juice was increased as well. The increase of juice viscosity might be attributed to the structure of gum that has long branches with bulky arrangement which capable in creating hydrogen bond with the water molecules, causing the increase of hydrodynamic volume, and thus forming viscous solution (Montenegro et al., 2012; Akkarachaneeyakorn and Tinrat, 2015).

\subsubsection{Turbidity}

Turbidity is the cloudiness and haziness of a liquid that occurred due to the colloidal and suspended polysaccharides like starch, pectin and hemicellulose components (Pinelo et al., 2010; Bajaj and Manhas, 
2012). In the current study, the addition of GA into roselle juice showed a significant effect on juice turbidity (Table 1). Sample D with the highest addition of GA $(6 \%)$ exhibited the highest turbidity value and this was reported to relate with its viscosity as well. Similarly, a study by Aghajanzadah et al. (2017) also reported that the addition of $0.1-0.2 \%$ xanthan gum into watermelon juice resulted in increase of cloudiness of the juice.

In roselle juice, the original turbidity might be contributed by the colloid polysaccharides particles like pectin and the partially dissolved insoluble components that suspended in juice (Pinelo et al., 2010; Kumar, 2015). The increase of juice turbidity with GA addition might be due to the electrostatic force between the cloud particles of the juice and GA molecule when added into the juice. The cloud particles in the juice usually were surrounded by negative charges (Yamasaki et al.,1964), while the GA molecules also were reported to have negative charges (Yamasaki et al., 1964; EspinosaAndrew et al., 2007). Therefore, the addition of GA into the juice might cause electrostatic repulsion forces between the negative-charged particles and GA molecules. Hence, the aggregation of the molecules in the juice can be avoided and thus maintained the suspension of the particles in the juice, resulting in higher turbidity and cloud stability. Besides, when compared with the viscosity property, the juice with higher turbidity was found to have higher viscosity as well. A similar result was reported by Akkarachaneeyakorn and Tinrat (2015) when evaluating the effect of hydrocolloids addition in mulberry juice, suggesting the linear relationship between viscosity and turbidity.

\subsubsection{Total anthocyanin content}

Anthocyanin is the water-soluble pigment responsible for the red colour of roselle juice. The anthocyanin content of roselle juice was ranged from $63.04 \pm 2.19$ to $83.74 \pm 2.17 \mathrm{mg} / 100 \mathrm{~mL}$ of the sample (Table 1). The amount of anthocyanin content in roselle juice without GA $(83.74 \pm 2.17 \mathrm{mg} / 100 \mathrm{~mL})$ was lower than reported in elderberry juice $(96.4 \pm 4.8 \mathrm{mg} / 100 \mathrm{~mL})$ and mulberry concentrate $(223.3 \mathrm{mg} / 100 \mathrm{~mL})$ as reported by Casati et al. (2015) and Kara and Ercelebi (2013), respectively. Nevertheless, the value was higher than reported in blackcurrant juice, pomegranate juice and roselle juice in previous studies (Turfan et al., 2011; Ibrahim and Mazuki, 2013; Dobson et al., 2017). The different in anthocyanin content in the juices may be due to the difference in their composition, $\mathrm{pH}$ value and production process which may affect the anthocyanin content.

GA was reported to enhance the stability of anthocyanin due to its structure as a highly branched heteropolymer of sugar with a small amount of protein that interacts with anthocyanin by hydrogen bond and forming non-covalent complexes (Mahdavi et al., 2016; Chung et al., 2016). According to Table 1, the current finding revealed that the addition of different concentrations of GA resulted in significant $(p<0.05)$ decreased of anthocyanin content in the juice. The decrease in anthocyanin content with GA addition showed the instability of this pigment when the gum was added, causing loss of anthocyanin pigments. A possible explanation for this result may be due to the "overcrowding" of the GA molecules in the drink when added at higher concentration. This reduced the interaction between anthocyanin and the glycoprotein of GA (Dror et al., 2006) that responsible to the anthocyanin stability. A similar trend was observed by Chung et al. (2016) who found that the anthocyanin stability decreased when $2.5-5.0 \%$ of GA was added into a model beverage that contained purple carrot anthocyanin.

\subsubsection{Colour}

The colour profile of roselle juice with different concentrations of GA addition was reported as $\mathrm{L}^{*}$ value (lightness), $\mathrm{a}^{*}$ value (redness and greenness) and $\mathrm{b}^{*}$ value (yellowness). As can be seen in Figure 1, there was no significant difference between the samples with different GA concentrations on $L^{*}$ attribute. This finding was supported by Pieczykolan and Kurek (2019) who also found no significant ( $p>0.05$ ) difference in lightness value of microcapsules containing anthocyanin from chokeberry with GA addition. Figure 1 also demonstrated that the redness and yellowness parameters decreased with increasing concentration of GA. The addition of GA at a minimum of $2 \%$ and $4 \%$ into roselle juice had reduced the yellowness and redness properties of roselle juice, respectively. The similar trend was also observed by Lachowicz et al. (2018) who found that the $a^{*}$ and $b^{*}$ of chokeberry juice were significantly decreased with guar gum addition. Previous studies had reported that the decrease of redness in juice might cause by the degradation of anthocyanin pigments in the samples, thus affect the redness property (Buvé et al., 2018; Liu et al., 2018). As supported in section 3.1.5, the present study also found a reduction in anthocyanin content when GA was added. Hence, the degradation of anthocyanin and losing the red pigments might be the main reason of colour degradation of roselle juice.

\subsection{Sensory evaluation}

Figure 2 presents the mean scores for the sensory assessment of roselle juice with GA addition at different concentrations. The acceptability of the juices was 


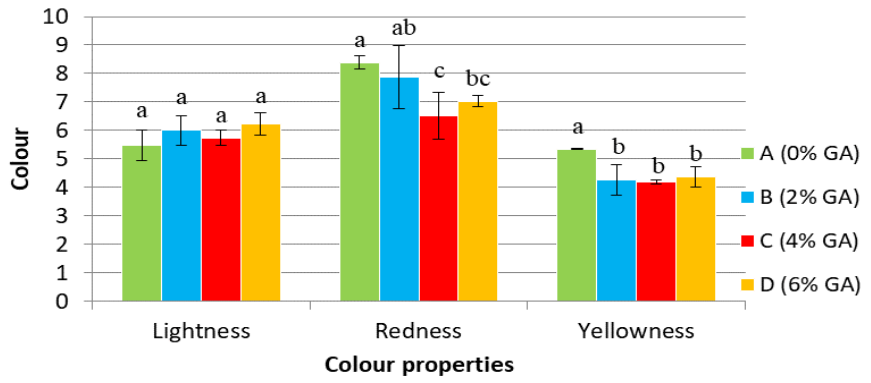

Figure 1. Colour intensity of roselle juice with different concentration of Gum Arabic (GA) $(n=3)$. Different letters above the bars indicate significant difference at the level of $\mathrm{p}<0.05$ within the sample.

analysed for their colour, odour, viscosity, taste and overall acceptability attributes on a 5-point hedonic scale. The result showed that all the samples obtained mean hedonic scores within the acceptability range with a score of equal or above 3.5 for all attributes. The statistical analysis of the sensory evaluation also revealed that there was no significant difference $(p>0.05)$ between the samples in all attributes except for the colour attribute $(\mathrm{p}<0.05)$.

For colour attribute, roselle juice with $2 \%$ of GA (sample B) attained significantly $(\mathrm{p}<0.05)$ higher acceptability score than the sample with $4 \%$ and $6 \%$ of GA (sample $\mathrm{C}$ and $\mathrm{D}$, respectively). Meanwhile, there was no significant difference between sample $B$ and control sample (sample A) in colour attribute. A similar result was obtained by Kiiru et al. (2018) when evaluating formulation of goat milk mozzarella cheese with the addition $2 \%, 3 \%$ and $4 \%$ A. senegal powder. The authors noted that colour acceptability score was the least for cheese containing 4\% A. senegal. As discussed in section 3.1.6, significant reduction of redness intensity was presented by roselle juices containing $4 \%$ and $6 \%$ GA. Hence, this finding might be the main reason for the lower acceptance score for these juices.

The current sensory acceptability test also demonstrated that there was no significant $(p>0.05)$ difference for the level of odour acceptability score of roselle juices containing GA as compared to the control sample. This might due to the properties of GA that is odourless and its addition in the food product does not affect the odour of the product (Featherstone, 2015). Besides, for the viscosity attribute, no significant difference $(p>0.05)$ was observed between the samples. Although previous result (viscosity property) showed that increasing the concentration of GA resulted in increasing the juice viscosity, however, sensory acceptability test showed all samples obtained similar acceptability scores between each other. Hence, this indicated that all panellists could accept the viscosity differences of roselle juice

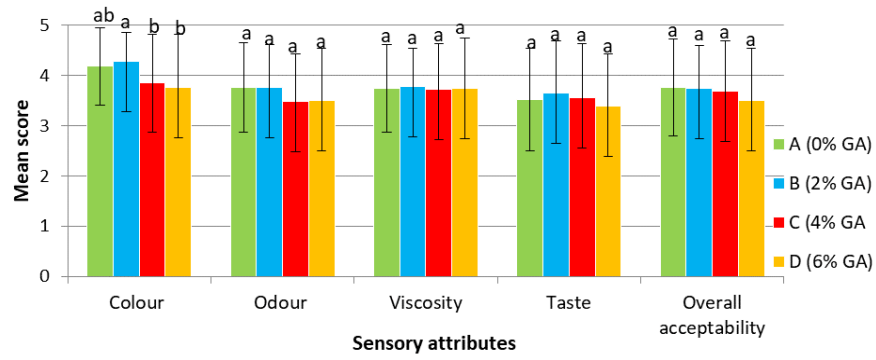

Figure 2. Sensory acceptability mean scores of prebiotic roselle juice with different concentration of Gum Arabic (GA) $(\mathrm{n}=50)$. Different letters above the bars indicate significant difference at the level of $p<0.05$, within the same attribute.

For taste attribute, different concentrations of GA addition in roselle juice also acquired similar acceptance level for all samples. This finding might be due to the tasteless characteristic of GA (Mohammed, 2015). A similar result was found by Elseed (2017), who reported that the addition of $A$. senegal powder in cow milk yoghurt did not significantly affect the taste of the samples during the sensory evaluation.

Finally, overall acceptability attributes gained equal acceptability score for all roselle juices regardless of their lower colour acceptance level obtained for sample with $4 \%$ and $6 \%$ of GA. Therefore, this finding showed that the addition of $2 \%$ to $6 \%$ of GA is applicable and considered had no impact on the organoleptic properties of roselle juice.

\section{Conclusion}

The result of the current study revealed that the physicochemical properties of roselle juice were affected by the addition of GA except for titratable acidity. The increase of GA concentration resulted in an increase of $\mathrm{pH}$, total soluble solids, viscosity and turbidity of roselle juice. However, the addition of GA had reduced the anthocyanin content of roselle juice. Besides, the addition of $\mathrm{GA}$ at a minimum of $2 \%$ and $4 \%$ also decreased the redness $\left(a^{*}\right)$ and yellowness $\left(b^{*}\right)$ properties of roselle juice, respectively. For sensory acceptability test, the addition of GA into roselle juice showed no effect on consumer acceptability except for colour attribute. Hence, this study revealed that roselle juices with GA addition were equally accepted as the juice without GA with more than $70 \%$ degree of likeness, suggesting their acceptability in the future market. As a summary, this study indicated that gum arabic (A. senegal) has the potential to be used as an alternative prebiotic source in food and beverage application, especially in the development of prebiotic roselle juice. 


\section{Conflict of Interest}

The authors declare no conflict of interest.

\section{Acknowledgements}

This research is a collaboration between Universiti Malaysia Terengganu (UMT), Universiti Teknologi MARA (UiTM) and Natural Prebiotic (M) Sdn. Bhd. Selangor, Malaysia. Special thanks to all for the great support throughout this study.

\section{References}

Aghajanzadeh, S., Ziaiifar, A.M. and Kashaninejad, M. (2017). Influence of thermal treatment, homogenization and xanthan gum on physicochemical properties of watermelon juice: A response surface approach. LWT - Food Science and Technology, 85(Part A), 66-74. https:// doi.org/10.1016/j.lwt.2017.07.007

Akim, A., Ling, L.C., Rahmat, A. and Zakaria, Z.A. (2011). Antioxidant and anti-proliferative activities of Roselle juice on Caov-3, MCF-7, MDA-MB-231 and HeLa cancer cell lines. African Journal of Pharmacy and Pharmacology, 5(7), 957-965.

Akkarachaneeyakorn, S. and Tinrat, S. (2015). Effects of types and amounts of stabilisers on physical and sensory characteristics of cloudy ready-to-drink mulberry fruit juice. Food Science and Nutrition, 3 (3), 213-220. https://doi.org/10.1002/fsn3.206

Al-Sheraji, S.H., Ismail, A., Manap, M.Y., Mustafa, S., Yusof, R.M. and Hassan, F.A. (2013). Prebiotics as functional foods: A review. Journal of Functional Foods, 5(4), 1542-1553. https://doi.org/10.1016/ j.jff.2013.08.009

Al-Wandawi, H. (2015). Organic acids composition of different parts of the medicinal plant - roselle (Hibiscus sabdariffa). International Journal of Biological and Pharmaceutical Research, 6(10), 808 -813 .

Bajaj, B.K. and Manhas, K. (2012). Production and characterisation of xylanase from Bacillus licheniformis $\mathrm{P} 11(\mathrm{C})$ with potential for fruit juice and bakery industry. Biocatalysis and Agricultural Biotechnology, 1(4), 330-337. https:// doi.org/10.1016/j.bcab.2012.07.003

BeMiller, J.N. (Ed.) (2019). Gum Arabic and Other Exudate Gums. In Carbohydrate Chemistry for Food Scientists, p. 313-321. United States: Woodhead Publishing. https://doi.org/10.1016/B978-0-12812069-9.00016-9

Buvé, C., Kebede, B.T., De Batselier, C., Carrillo, C., Pham, H.T.T., Hendrickx, M., Grauwet, T. and Van
Loey, A. (2018). Kinetics of colour changes in pasteurised strawberry juice during storage. Journal of Food Engineering, 216, 42-51. https:// doi.org/10.1016/j.jfoodeng.2017.08.002

Calame, W., Weseler, A.R., Viebke, C., Flynn, C. and Siemensma, A.D. (2008). Gum arabic establishes prebiotic functionality in healthy human volunteers in a dose-dependent manner. British Journal of Nutrition, 100(6), 1269-1275. https:// doi.org/10.1017/S0007114508981447

Casati, C.B., Baeza, R., Sanchez, V., Catalano, A., López, P. and Zamora, M.C. (2015). Thermal degradation kinetics of monomeric anthocyanins, colour changes and storage effect in elderberry juices. Journal of Berry Research, 5(1), 29-39. https://doi.org/10.3233/JBR-150088

Cherbut, C., Michel, C., Raison, V., Kravtchenko, T. and Severine, M. (2003). Acacia gum is a bifidogenic dietary fibre with high digestive tolerance in healthy humans. Microbial Ecology in Health and Disease, 15(1), 43-50. https:// doi.org/10.1080/08910600310014377

Chung, C., Rojanasasithara, T., Mutilangi, W. and McClements, D.J. (2016). Enhancement of colour stability of anthocyanins in model beverages by gum arabic addition. Food Chemistry, 201, 14-22. https:// doi.org/10.1016/j.foodchem.2016.01.051

Cisse, M., Vaillant, F., Kane, A., Ndiaye, O. and Dornier, M. (2012). Impact of the extraction procedure on the kinetics of anthocyanin and colour degradation of roselle extracts during storage. Journal of the Science of Food and Agriculture, 92 (6), 1214-1221. https://doi.org/10.1002/jsfa.4685

da Silva, I.M., Rabelo, M.C. and Rodrigues, S. (2014). Cashew juice containing prebiotic oligosaccharides. Journal of Food Science and Technology, 51(9), 2078-2084. https://doi.org/10.1007/s13197-0120689-9

Dauqan, E. and Abdullah, A. (2013). Utilisation of gum Arabic for industries and human health. American Journal of Applied Sciences, 10(10), 1270-1279. https://doi.org/10.3844/ajassp.2013.1270.1279

Dobson, G., McDougall, G.J., Stewart, D., Cubero, M.Á. and Karjalainen, R.O. (2017). Effects of Juice Matrix and Pasteurization on Stability of Black Currant Anthocyanins during Storage. Journal of Food Science, 82(1), 44-52. https://doi.org/10.1111/17503841.13575

Dror, Y., Cohen, Y. and Yerushalmi-Rozen, R. (2006). Structure of Gum Arabic in Aqueous Solution. Journal of Polymer Science, 44, 3265-3271. https:// doi.org/10.1002/polb.20970 
Elseed, W.A.M.G. (2017). Effect of Gum Arabic Powder on Physicochemical and Sensory Properties of Cow Milk Yogurt. Gezira: University of Gezira, MSc. Dissertation.

Espinosa-andrews, H., Baez-Gonzalez, J.G., Cruz-sosa, F. and Vernon-carter, E.J. (2007). Gum Arabic Chitosan Complex Coacervation. Biomacromolecules, 8, 1313-1318. https:// doi.org/10.1021/bm0611634

Featherstone, S. (Ed.) (2015). Ingredients used in the preparation of canned foods. In A Complete Course in Canning and Related Processes, p. 147-211. United Kingdom: Woodhead Publishing. https:// doi.org/10.1016/B978-0-85709-678-4.00008-7

Formagio, A., Ramos, D., Vieira, M., Ramalho, S., Silva, M., Zárate, N., Foglio, M.A. and Carvalho, J. (2015). Phenolic compounds of Hibiscus sabdariffa and influence of organic residues on its antioxidant and antitumoral properties. Brazilian Journal of Biology, 75(1), 69-76. https://doi.org/10.1590/15196984.07413

Ghavidel, R.A., Karimi, M., Davoodi, M., Jahanbani, R. and Asl, A.F.A. (2014). Effect of fructooligosaccharide fortification on quality characteristic of some fruit juice beverages (apple and orange juice ). International Journal of Farming and Allied Sciences, 3(2), 141-146.

Gibson, G.R., Hutkins, R., Sanders, M.E., Prescott, S.L., Reimer, R.A., Salminen, S.J., Scott, K., Shanton, C., Swanson, K.S., Cani, P.D., Verbeke, K. and Reid, G. (2017). Expert consensus document: The International Scientific Association for Probiotics and Prebiotics (ISAPP) consensus statement on the definition and scope of prebiotics. Nature Reviews Gastroenterology and Hepatology, 14, 491-502. https://doi.org/10.1038/nrgastro.2017.75

Gomes, W.F., Tiwari, B.K., Rodriguez, Ó., de Brito, E.S., Fernandes, F.A.N. and Rodrigues, S. (2017). Effect of ultrasound followed by high pressure processing on prebiotic cranberry juice. Food Chemistry, 218, 261-268. https://doi.org/10.1016/ j.foodchem.2016.08.132

Granato, D., de Castro, I.A., Ellendersen, L.S.N. and Masson, M.L. (2010). Physical stability assessment and sensory optimisation of a dairy-free emulsion using response surface methodology. Journal of Food Science, 75(3), 149-155. https:// doi.org/10.1111/j.1750-3841.2010.01514.x

Ibrahim, R. and Mazuki, N.A.F. (2013). The quality of roselle (Hibiscus sabdariffa L.) juices made from roselle calyces stored at different cold temperatures. Malaysian Applied Biology, 42(1), 67-71.
Idris, O.H.M. (2017). What is gum arabic? an overview. International Journal of Sudan Research, 7(1), 1-14.

Jabeur, I., Pereira, E., Barros, L., Calhelha, R.C., Soković, M., Oliveira, M.B.P.P. and Ferreira, I.C.F.R. (2017). Hibiscus sabdariffa L. as a source of nutrients, bioactive compounds and colouring agents. Food Research International, 100(Part 1), 717-723. https://doi.org/10.1016/j.foodres.2017.07.073

Jung, E., Kim, Y. and Joo, N. (2013). Physicochemical properties and antimicrobial activity of Roselle (Hibiscus sabdariffa L.). Journal of the Science of Food and Agriculture, 93(15), 3769-3776. https:// doi.org/10.1002/jsfa.6256

Kara, Ş. and Ercẹlebi, E.A. (2013). Thermal degradation kinetics of anthocyanins and visual colour of Urmu mulberry (Morus nigra L.). Journal of Food Engineering, 116(2), 541-547. https:// doi.org/10.1016/j.jfoodeng.2012.12.030

Kiiru, S.N., Mahungu, S.M. and Omwamba, M. (2018). Preparation and analysis of goat milk mozzarella cheese containing soluble fiber from Acacia senegal var. kerensis. African Journal of Food Science, 12 (3), 46-53. https://doi.org/10.5897/AJFS2017.1652

Kumar, S. (2015). Role of enzymes in fruit juice processing and its quality enhancement. Advances in Applied Science Research, 6(6), 114-124.

Lachowicz, S., Oszmianski, J. and Kalisz, S. (2018). Effects of various polysaccharide clarification agents and reaction time on content of polyphenolic compound, antioxidant activity, turbidity and colour of chokeberry juice. LWT, 92, 347-360. https:// doi.org/10.1016/j.lwt.2018.02.054

Lau, T., Chan, M.W., Tan, H.P. and Kwek, C.L. (2013). Functional food: A growing trend among the health conscious. Asian Social Science, 9(1), 198-208. https://doi.org/10.5539/ass.v9n1p198

Lee, J. (2005). Determination of Total Monomeric Anthocyanin Pigment Content of Fruit Juices, Beverages, Natural Colorants, and Wines by the $\mathrm{pH}$ Differential Method: Collaborative Study. Journal of AOAC International, 88(5), 1269-1278.

Liu, Y., Yang, P., Yuan, C., Wang, H., Han, F., Liu, Y. and Wang, L. (2018). Stability of anthocyanins and their degradation products from cabernet sauvignon red wine under gastrointestinal $\mathrm{pH}$ and temperature conditions. Molecules, 23(354), 1-20. https:// doi.org/10.3390/molecules23020354

Magwaza, L.S. and Opara, U.L. (2015). Analytical methods for determination of sugars and sweetness of horticultural products - A review. Scientia Horticulturae, 184, 179-192. https:// doi.org/10.1016/j.scienta.2015.01.001 
Mahdavi, S.A., Jafari, S.M., Assadpoor, E. and Dehnad, D. (2016). Microencapsulation Optimization of Natural Anthocyanins with Maltodextrin, gum Arabic and Gelatin. International Journal of Biological Macromolecules, 85, 379-385.

Mardiah, Zakaria, F.R., Prangdimurti, E. and Damanik, R. (2014). The Effect of Roselle Extract (Hibiscus sabdariffa Linn.) On Blood Glucose Level and Total Antioxidant Level on Diabetic Rat Induced By Streptozotocin. IOSR Journal of Pharmacy (IOSRPHR), 4(10), 08-16. https:// doi.org/10.9790/3013-0401008016

Mariod, A.A. (Ed.). (2018). Functional Properties of Gum Arabic. In Gum Arabic: Structure, Properties, Application and Economics, p. 283-295. United Kingdom: Elsevier Inc. https://doi.org/10.1016/B978 -0-12-812002-6.00024-5

McKay, D.L., Chen, C.-Y.O., Saltzman, E. and Blumberg, J.B. (2010). Hibiscus tea (Hibiscus sabdariffa L.) lowers blood pressure in pre-and mildly hypertensive adults. The Journal of Nutrition, 140(2), 298-303. https://doi.org/10.3945/ jn.109.115097

Mgaya-Kilima, B., Remberg, S.F., Chove, B.E. and Wicklund, T. (2014). Physio-chemical, mineral composition and antioxidant properties of roselle. African Journal of Food, Agriculture, Nutrition and Development, 14(3), 8963-8978.

Mohammed, A.M.E. (2015). Estimation of the Active Components in Gum Arabic Collected from Western Sudan. International Journal of Science and Research, 6(3), 1262-1282.

Montenegro, M.A., Boiero, M.L., Valle, L. and Borsarelli, C.D. (2012). Gum Arabic: More Than an Edible Emulsifier. In Verbeek, D.J. (Ed.). Products and Applications of Biopolymers, p. 1-26. Croatia: InTech Open.

Nami, Y., Haghshenas, B. and Yari Khosroushahi, A. (2016). Effect of psyllium and gum Arabic biopolymers on the survival rate and storage stability in yogurt of Enterococcus durans IW3 encapsulated in alginate. Food Science and Nutrition, 5(3), 1-10. https://doi.org/10.1002/fsn3.430

Nayak, P.K., Rayaguru, K. and Radha Krishnan, K. (2017). Quality comparison of elephant apple juices after high-pressure processing and thermal treatment. Journal of the Science of Food and Agriculture, 97 (5), 1404-1411. https://doi.org/10.1002/jsfa.7878

Niamah, A.K., AL-Sahlany, S.T.G. and Al-Manhel, A.J. (2016). Gum Arabic Uses as Prebiotic in Yogurt Production and Study Effects on Physical, Chemical Properties and Survivability of Probiotic Bacteria
During Cold Storage. World Applied Sciences Journal, 34(9), 1190-1196.

Nwaokoro, O.G. and Akanbi, C.T. (2015). Effect of the addition of hydrocolloids to tomato-carrot juice blend. Journal of Nutritional Health and Food Science, 3(1), 1-10. https://doi.org/10.15226/ jnhfs.2015.00134

Oke, M., Jacob, J.J. and Paliyath, G. (2010). Effect of soy lecithin in enhancing fruit/sauce quality. Food Research International, 43, 232-240. https:// doi.org/10.1016/j.foodres.2009.09.021

Parnanto, N.H.R., Yudhistira, B., Pertiwi, S.R. and Pangestika, A. (2018). The effect of CMC and arabic gum stabiliser combination on the characteristics of soursop velva (Annona muricata L). IOP Conference Series: Earth and Environmental Science, 142, 012 027.

$1315 / 142 / 1 / 012027$

https://doi.org/10.1088/1755-

Patel, S. and Goyal, A. (2012). The current trends and future perspectives of prebiotics research: a review. 3 Biotech, 2(2), 115-125. https://doi.org/10.1007/ s13205-012-0044-x

Phillips, A.O. and Phillips, G.O. (2011). Biofunctional behaviour and health benefits of a specific gum arabic. Food Hydrocolloids, 25(2), 165-169. https:// doi.org/10.1016/j.foodhyd.2010.03.012

Pieczykolan, E. and Kurek, M.A. (2019). Use of guar gum, gum arabic, pectin, beta-glucan and inulin for microencapsulation of anthocyanins from chokeberry. International Journal of Biological Macromolecules, 129, 665-671. https:// doi.org/10.1016/j.ijbiomac.2019.02.073

Pinelo, M., Zeuner, B. and Meyer, A.S. (2010). Juice clarification by protease and pectinase treatments indicates new roles of pectin and protein in cherry juice turbidity. Food and Bioproducts Processing, 88 (2-3), 259-265. https://doi.org/10.1016/ j.fbp.2009.03.005

Riaz, G. and Chopra, R. (2018). A review on phytochemistry and therapeutic uses of Hibiscus sabdariffa L. Biomedicine and Pharmacotherapy, 102, 575-586. https://doi.org/10.1016/ j.biopha.2018.03.023

Saxena, D., Sabikhi, L., Chakraborty, S.K. and Singh, D. (2014). Process optimisation for enzyme aided clarification of watermelon juice. Journal Food Science Technology, 51(10), 2490-2498. https:// doi.org/10.1007/s13197-012-0720-1

Shukri, W.H.Z., Hamzah, E.N.H., Halim, N.R.A., Isa, M.I.N. and Sarbon, N.M. (2014). Effect of different types of hydrocolloids on the physical and sensory properties of ice cream with fermented glutinous rice 
(tapai pulut), International Food Research Journal, 21(5), 1777-1787.

Sreenath, H.K. and Santhanam, K. (1992). The use of commercial enzymes in white grape juice clarification. Journal of Fermentation and Bioengineering, 73(3), 241-243. https:// doi.org/10.1016/0922-338X(92)90171-P

Talpur, A.R., Soomro, A.H., Khaskheli, M., Shah, A.H., Mangsi, A.S. and Talpur, B.R. (2016). Effect of Hydrocolloids on Physico-Chemical and Sensory Quality of Whey Beverages. IOSR Journal of Environmental Science, Toxicology and Food Technology, 10(7), 79-85.

Turfan, Ö., Türkyilmaz, M., Yemi, O. and Özkan, M. (2011). Anthocyanin and colour changes during processing of pomegranate (Punica granatum L.; Cv. Hicaznar) juice from sacs and whole fruit. Food Chemistry, 129(4), 1644-1651. https:// doi.org/10.1016/j.foodchem.2011.06.024

Tyl, C. and Sadler, G.D. (2017). pH and Titratable Acidity. In Nielsen, S.S. (Ed.). Food Analysis, p. 389 -406). USA: Springer International Publishing. https://doi.org/10.1007/978-3-319-45776-5_22

Yamasaki, M., Yasui, T. and Arima, K. (1964). Pectic Enzymes in the Clarification of Apple Juice.Agricultural and Biological Chemistry, 28(11), 779-787. https://doi.org/10.1271/bbb1961.28.779 